\title{
Innovative buildings and structures as a means of humanization of urban space
}

\author{
Maksim Votinov ${ }^{1}$, Olga Smirnova ${ }^{2}$ \\ ${ }^{1}$ Department of the Bases of Architectural Design and Illustration, \\ Faculty of Architecture, Design and Arts, O.M. Beketov \\ National University of Urban Economy in Kharkiv,e-mail: votinelly@ukr.net \\ ${ }^{2}$ Department of the Architecture of Buildings and Structures and the Design of Architectural Envi- \\ ronment, Faculty of Architecture, Design and Arts, O.M. Beketov \\ National University of Urban Economy in Kharkiv, e-mail: o.l-y.a@mail.ru
}

\begin{abstract}
Innovative buildings and structures as a means of humanization of urban space are considered. Innovative buildings and structures are designed for various processes of human life. Innovative buildings are the objects of technologies, where the latest achievements in various fields of science and technology are realized. They were created gradually in the process of civilization development, but at all the stages of historical development they were distinguished by their novelty (they didn't have analogs), their unconventional constructive and compositional space-spatial solution which provides the individual artistic image of the object. These buildings should be differentiated into historical and modern. At each stage of historical development, they were architectural objects with new qualitative characteristics. The main patterns in the formation of innovative historical and modern objects are identified. The application of the phenomenological concept in the design of innovative buildings, when the architectural environment acquires its properties depending on the spatial - physical and utilitarian - needs of a human, where a person is viewed as a functioning object, as well as spiritual-aesthetic needs, where a person is considered as a perceiving subject, becomes urgent. The aspects of the humanization of the urban environment that innovative buildings should fulfill are determined.
\end{abstract}

Keywords: Innovative buildings, humanization, urban space.

\section{Introduction}

Innovative buildings and structures become an integral element of the urban environment. They are designed for various processes of human life. At present, the engineering and technical level of human life support has increased immeasurably, which requires qualitatively new approaches in improving of the formation of the urban environment, especially in view of humanization of its infrastructure.

It is necessary to search for effective ways of improvement of the living environment to create a high quality of life in the city.

Creating a high quality of life in the city - is the cumulative result of the integrated activities of economic and social planning, architectural and urban design as well as the entire sphere of implementation of decision-making. Therefore, urban environment is considered as an object of complex systemic dynamic development, in which innovative buildings are the objects of technologies, where the latest achievements in various fields of science and technology are realized. They, in fact, are stimulators of the scientific and technical process at all stages of historical development. 
To determine the patterns and features of the formation of innovative objects, criteria for their analysis have been developed. These are town-planning, functional, aesthetics, ecological Landscaping, constructive -technological.

These criteria allow us to identify morphological, semantic, functional, aesthetic, constructive-technological features of the formation of innovative objects.

The morphological aspect of the examination will reveal the compositional features of the formation of buildings and structures and also determine their basic structure-forming elements.

The semantic aspect of the examination makes it possible to reveal the meaningful, semantic nature of the organization of the building's volume, which will allow interpretation of the created object in the deep range of cultural and historical values and values of this civilization.

Functional aspect will reveal the functional purpose of the object, the specific character of the main processes of activity in it.

The aesthetic aspect of the examination will allow us to identify the artistic impression of the architectural object, taking into account the styles of the main elements, this aspect of the examination will also allow us to determine the various methods of construction of the buildings, taking into account the modulation of vertical and horizontal surfaces to create its individual and geometric shape, scale characteristics, color and light.

The constructive and technological aspect of the examination will reveal the tectonics of buildings, structures and their main supporting elements.

The structural qualities of the architecture of buildings and structures provide durability and stability.

Taking into account the described features of the formation of buildings and structures, a chronological scale of innovative historical and modern buildings in the urban environment has been determined.

Historical innovative buildings and structures appeared at the early stages of the development of civilization.

Historical innovative objects are buildings and structures with an individual artistic image, unconventional constructive system, the creation of which is conditioned by the socio-cultural needs of a certain epoch. The Gardens of the Semiramis, the Acropolis of Athens, the Colosseum, the Gothic temple of Notre Dame, the Crystal Palace and the Eiffel Tower Historic should be considered as innovative objects.

The Gardens of the Semiramis, according to archaeological material, were a series of towering terraces. The terraces were connected by monumental staircases of white and pink marble. Gardens of the Semiramis are innovative and bold on a constructive solution. They are related to the seven wonders of the world. The main structure-forming elements of this object are terraces. This was the initial stage of the emergence of architecture with high artistic value, which includes elements of the natural environment.

The next period for the creation of unique architectural and town-planning objects is the era of antiquity.

The main historical innovative architectural and urban objects were buildings and structures, but in the same period an innovative architectural and urban ensemble have appeared in Ancient Greece. It was the Acropolis of Athens. A collection of architectural structures which have artistic and planning unity and spatially cooperated with each other was represented there.

The Colosseum is the largest amphitheater in Rome. Elliptical in terms of (dimensions in the main axes of about $156 * 188 \mathrm{~m})$ and grandiose in height $(48.5 \mathrm{~m})$, it accommodated up to 50 thousand spectators. This is the first example of a bold solution of tent construc- 
tions known in history as a periodically arranged covering. The external appearance of the Colosseum is monumental due to the huge size and unity of the flexible design of the wall in the form of a multi-tiered orders of arches. The Colosseum became known as an innovative architectural structure, far ahead of its day, thanks to its technical equipment, a new functional purpose with the use of the atricalization in a building with a spectacular function and the use of underground space.

The technical breakthrough of the Gothic architects was the discovery of a new way of distributing the load by means of a gothic skeleton. The Gothic temple of Notre Dame should be considered an innovative building of the medieval period. It is a sacred object with a dynamic volume and the use of an unconventional stone frame system with a crocheted arch, flying buttress and counter forts.

The Crystal Palace is a public building with an exhibition function that includes natural components (a winter garden) with the use of modular elements made of metal and glass. The building did not have a prototype in the history of architecture. The construction was one of the first examples of the use of unified elements in construction. The Crystal Palace has also become the world's first large metal-framed building and the first building with glass walls.

The Eiffel Tower is a dynamic design of metal platforms and columns with a vertical composite axis acting as a dominant in the urban environment. It was the highest monument of the world until 1941. Now its height is $324 \mathrm{~m}$. Since 1991, the Eiffel Tower was included in the UNESCO World Heritage List.

Modern innovative objects include the Solomon R. Guggenheim Museum in New York, the Sydney Opera House, the "Metropol Parasol" Cultural Center in Seville (Spain), the Marina Bay Sands Hotel in Singapore, the Dancing Dragons Multifunctional Complex in Seoul (South Korea) and Burj Khalifa in Dubai.

The Solomon R. Guggenheim Museum in New York is a convoluted volume reflecting the functional purpose of the spectacular public building with an unconventional system of exposure examination and various interior spaces combined with an atrium. Outwardly, the museum looks like an inverted pyramidal tower. This building is considered as one of the most striking works in architecture of the twentieth century.

Sydney Opera House is a unique spatial shell-form building, reflecting the nature of the surrounding environment and restraining the boundaries of the interior space together with integration of interior and exterior spaces. Its shell form creates an unconventional artistic image of the object. The artistic image enhances the function of the natural environment in the form of water surfaces. The Opera House is recognized as one of the most remarkable buildings of modern architecture.

The "Metropol Parasol" Cultural Center is a multifunctional, multilevel object with a unique space-spatial structure of a honeycomb construction made of wooden prefabricated panels which create an unconventional artistic image. [3]

Marina Bay Sands Hotel in Singapore is a multifunctional complex with a dynamic volume and an innovative design that allow to create a recreational environment with a great swimming pool and observation platforms on its roof (on the height of $200 \mathrm{~m}$ ). It has high ecological characteristics of the environment. [4]

The "Dancing Dragons" multifunctional complex in Seoul is a unique object, whose artistic image reflects the national characterwith the help of itsspace-spatial solution. It is a resource-ecological object with the use of a system of diverse technologies that make possible creatingmore comfortable living environment.

The Burj Khalifa multifunctional complex in Dubai is the tallest building in the world (828 $\mathrm{m}$ high). The artistic image of the building is represented by a stalagmite. The space- 
spatial structure of the building is organically connected with the surrounding natural environment specially created with the use of all means of landscape design for viewing expositions from specific sites located at different heights. The complex is outfitted with all the necessary equipment for the formation of comfortable environment. [5]

It should be noted that in the XXI century, in order to implement radical changes in the architectural and town-planning formations to enhance the ecological and aesthetic potential of the modern urban environment, it was necessary to create a fundamentally new architecture of buildings. Studying the ways of humanizing urban spaces by means of creating innovative buildings is an essential aspect of improving the quality of the human environment. Humanization of the architectural environment should be understood as a process and method of improving the quality (improvement) of the architectural environment, aimed at achieving maximum comfort of human life in all its spheres by appropriate functional-utilitarian and spiritual-aesthetic organization of the material-spatial shell. [6]

Thus, the formation of innovative buildings and structures in the urban environment from the perspective of its humanization will allow for more effective solutions. Such an approach enriches the architectural environment of the city, improves the processes of shaping both the architectural interior and exterior environment of individual objects, and the city as a whole, taking into account the growing human and societal needs.

The application of the phenomenological concept in the design of innovative buildings, when the architectural environment acquires its properties depending on the spatial physical and utilitarian - needs of a human, where a person is viewed as a functioning object, as well as spiritual-aesthetic needs, where a person is considered as a perceiving subject, becomes urgent (Fig. 1).

Taking into account the spatial needs of a person, innovative buildings must fulfill the following aspects of the humanization of the urban environment: utilitarian and functional, emotional and artistic-imaginative.

In modern conditions, the creation of such innovative buildings and structures is a priority.

\section{Conclusions}

It is allowed to formulate the following conclusions:

1. The analysis of practical experience in the formation of innovative buildings as means of humanizing the urban environment made it possible to reveal the evolution of their creation (Fig. 2).

It is determined that innovative historical buildings and structures were created in preindustrial and industrial periods of development. They were formed before the twentieth century. During the four stages of historical development: ancient (I millennium BC), antique (486 AD), medieval (V-XV centuries) and industrial revolutions (XVI-XIX centuries).

Modern innovative architectural objects in the post-industrial period of development (XX-XXI centuries) were created in stages in accordance with the social and temporal needs of society. Three stages are to be distinguished in their formation: organic (beginning, mid-20th century), aesthetic-communication (middle, late 20th century), and ecological resource (XXI century).

2. The main regularities in the formation of historical and modern innovative buildings and structures in the urban environment are revealed.

The main patterns in the formation of innovative historical objects are: the prevalence of the regular structure; increase in the scale characteristics of objects; the use of composi- 
tional means in accordance with the tectonics of structures; the presence of a certain symbolism, the identification of individual stylistics; the emergence of structures with a diverse functions: recreational, spectacular, sacral; the presence of an individual artistic image with a huge emotional impact on a person; the creation of facilities with the use of new technologies and unconventional structures.

The main patterns in the formation of innovative modern facilities are: the integration of buildings with the nature; increasing the height of buildings as a criterion for the formation of an innovative object; identification of the informative value of buildings in accordance with their functions; the tendency to the formation of multifunctional objects, the complication of the functional structure of buildings; expressionism in the creation of the artistic image of objects; usage of underground urban techniques, the use of new technologies with natural energy systems in design solutions.

It should be noted that one of the regularities in the formation of innovative historical and modern buildings is their scale. As shown by the analysis of the formation of innovative buildings, scale is one of the most expressive means in the volumetric-spatial composition of any object.

\section{References}

1. Krizhanovskaya N.Y., Smirnova O.V., Etymology of the term «innovation» in the architectural and town-planning activity. International Scientific Journal 2 (2016) 10-14.

2. Krizhanovskaya N.Y., Smirnova O.V., Genesis formirovaniya innovacionnih zdanii i soorujenii $v$ gorodskoi srede: monograph. Kh. KhNUGH 189 (2016).

3. Lokotko A.I. Architecture: avant-garde, absurdity, fantasy. Minsk, Belarus, Navuka 206 (2012).

4. Pokka E.V. Bridges and covered transitions in architecture of multipurpose public complexes [electronic resource]. News of KGASU, 3 (37) (2016). - Access mode: http://izvestija.kgasu.ru/files/3_2016/49_55_Pokka.pdf.

5. "Burj Khalifa". Na recordnoi visote visokih tehnologii [electronic resource]. Zdaniya visokih technologii 1 (2014) - Access mode:

http://zvt.abok.ru/articles/183/Burdzh_Halifa_Na_rekordnoi visote visokih tehnologii.

6. Votinov M.A. Humanization of object-spatial environment of the center of the largest city. Problemy teorii i istorii arkhitektury Ukrainy. Sbornik nauchnykh trudov. Odessa: OGASA 15 (2015) 138-144. 


\begin{tabular}{|c|c|}
\hline \multicolumn{2}{|c|}{ FEATURES OF HUMANIZATION OF THE URBAN ENVIRONMENT IN VIEW OF HUMAN FACTOR } \\
\hline $\begin{array}{c}\text { HUMAN AS A } \\
\text { FUNCTIONING SUBJECT }\end{array}$ & $\begin{array}{l}\text { HUMAN AS A PERCIEVING } \\
\text { SUBJECT }\end{array}$ \\
\hline $\begin{array}{c}\text { FUNCTIONAL CHARACTERISTICS OF THE } \\
\text { ARCHITECTURAL ENVIRONMENT OF } \\
\text { BUILDINGS }\end{array}$ & $\begin{array}{l}\text { PERCIEVED QUALITIES OF THE } \\
\text { ARCHITECTURAL ENVIRONMENT OF } \\
\text { BUILDINGS }\end{array}$ \\
\hline $\begin{array}{ll}\text { - } & \text { PRECENSE OF ALL NECESSARY FUNCTIONAL } \\
\text { ZONES; } \\
\text { - } \\
\text { CAPACITY OF ARCHITECTURAL OBJECTS } \\
\text { WHICH IS RELEVANT WITH BUILDING'S } \\
\text { FUNCTIONS; } \\
\text { OPTIMAL SPACE-SPATIAL CONTENT, } \\
\text { DEFINED BY THE FUNCTIONAL PROCESS; } \\
\text { - FUNCTIONAL AND ECOLOGICAL COMFORT } \\
\quad \text { OF THE ENVIRONMENT }\end{array}$ & $\begin{array}{ll}- & \text { SAFITY, COMMUNICATIVENESS; } \\
\text { AESTHETIC ATTRACTIVENESS CAUSED BY } \\
\text { COMPOSITION CHARACTERISTICS OF THE } \\
\text { ENVIRONMENT; } \\
\text { OBJECT'S RECOGNIZABILITY AND CLEAR } \\
\text { ORIENTATION IN SPACE; } \\
\text { INTEGRITY AND INDIVIDUALITY OF THE } \\
\text { ARTISTIC IMAGES OF BUILDINGS }\end{array}$ \\
\hline
\end{tabular}

\section{CHARACTERISTICS OF INNOVATIVE BUILDINGS AND THEIR POSITIVE INFLUENCE ON THE DEVELOPMENT OF URBAN ENVIRONMENT}

STAGED FORMATION OF INNOVATIVE BUILDINGS IN VIEW OF TECHNICAL OPPORTUNITIES AND AESTHETIC IDEALS OF A CERTAIN EPOCH

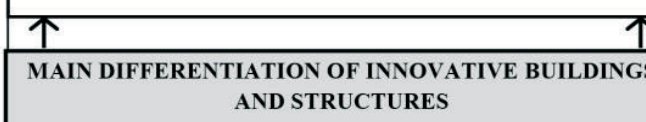
AND STRUCTURES
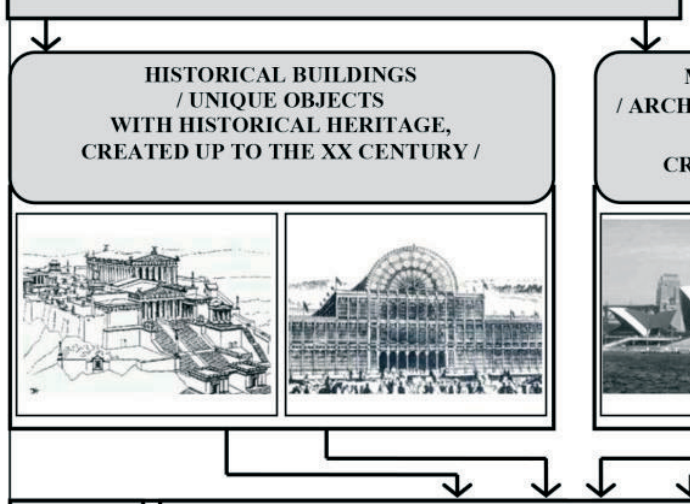

MODERN INNOVATIVE BUILDINGS I ARCHITECTURAL OBJECTS WITH EFFECTIVE TECHNICAL SOLUTION,

CREATED IN THE XX-XXI CENTURIES /

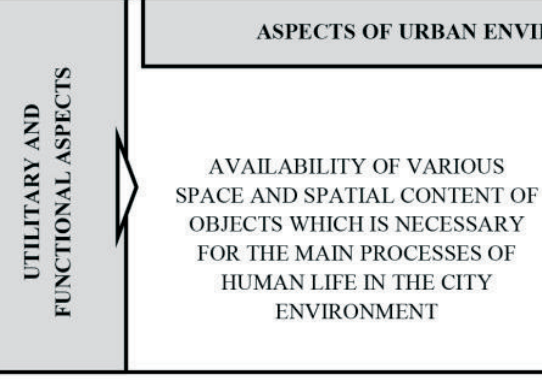

INNOVATIVE BUILDINGS ARE UNIQUE ENVIRONMENTAL OBJECTS WITH A SPECIFIC FUNCTIONAL APPOINTMENT, INTENDED FOR DIFFERENT PROCESSES OF HUMAN LIFE ACTIVITY IN THE CITY ENVIRONMENT

- USAGE OF UNDERGROUND

URBANISTIC METHODS;

- APPLICATION OF TECHNOLOGIES

BASED ON NATURAL ENERGY

SYSTEM:

- INTEGRATION OF BUILDINGS WITH

NATURAL ENVIRONMENT
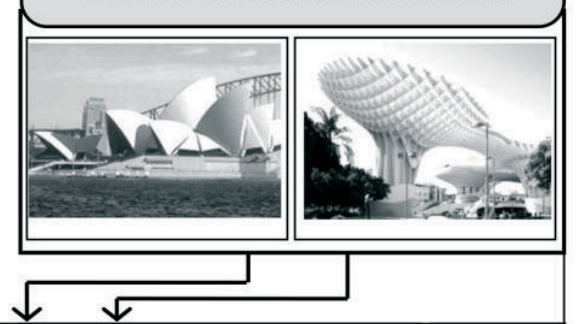

ONMENT HUMANIZATION

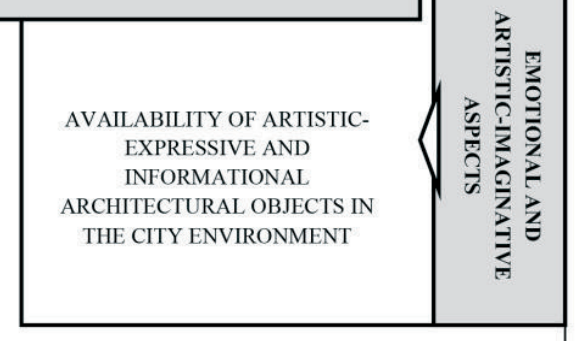

Fig. 1. Innovative buildings as a means of humanization of urban environment 


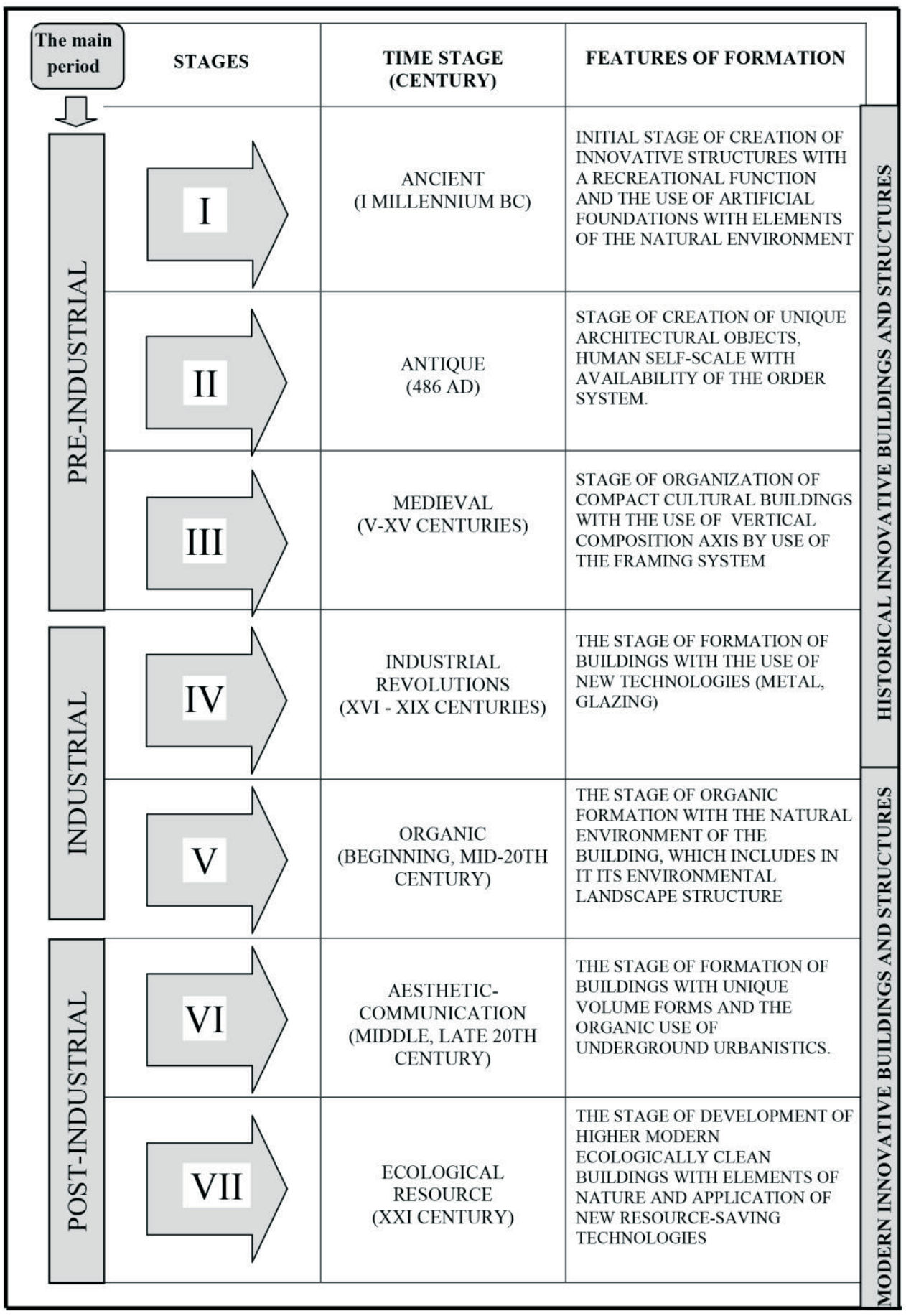

Fig. 2. Periods and stages of formation of innovative buildings and structures in the urban environment 